\title{
Pre-Analytical Challenges during RAS Testing: Tissue Quality and the Estimation of Neoplastic Cell Percentage
}

\section{Abstract}

Laboratories require customized feedback on improving biomarker testing practices. A workshop was organized for laboratories that participated in a European external quality assessment scheme to resolve issues related to the estimation of neoplastic cell percentage and tissue quality for RAS testing for colorectal cancer.

An interactive course about tissue quality took place to stress the importance of the pre-analytical phase. During a microscopic session, five H\&E stained tumor tissue slides were discussed and neoplastic cell percentages estimated. Participants included 4 pathologists, 3 molecular biologists, a technologist and a clinical geneticist from 7 laboratories. In six laboratories, tumor contents are checked routinely by visual estimation by the pathologist. The average difference between the lowest and highest estimation was $22 \%$.

During the workshop the importance of the pre-analytical phase was stressed and feedback was provided. Such initiatives can contribute in improving biomarker testing standards in Europe

Keywords Neoplastic Cell content; Variation; Pathologist training; Quality improvement.

Received: March 13, 2019; Accepted: July 19, 2019; Published: July 26, 2019

\section{Introduction}

Since the introduction of precision medicine, where treatments are tailored to specific genetic alterations, clinical decisions rely on accurate test outcomes. For example, the treatment of patients with metastatic colorectal cancer (mCRC) with EGFR-targeting drugs requires a confirmed wild-type status of both the KRAS and NRAS genes (exon 2, 3 and 4) [1]. Correct test outcomes are dependent on both the quality of a test method and the specimen quality (e.g. tissue fixation, tumor size and cellularity, sample type) [2]. This requires harmonization in the pre-analytical phase, which is highly error prone $[3,4]$. External Quality Assessment (EQA) programs have been set up to ensure quality, however, additional customized feedback is also important for improving laboratory procedures [5].

False negative results can arise when the amount of tumor DNA in the sample is lower than the amount that is required for the test method. This can be translated into a minimum number of neoplastic cells [6]. Processes such as selection of the most
Dufraing $\mathrm{K}^{1,2}$, Keppens $C^{1}$, Siebers AG $^{2}$, Kafatos $\mathrm{G}^{3}$, Lowe $\mathrm{K}^{4}$, Demonty $\mathrm{G}^{5}$, Dequeker EMC ${ }^{1 *}$ and Van Krieken $\mathrm{JH}^{2}$

1 Department of Public Health and Primary Care, Biomedical Quality Assurance Research Unit, Leuven, University of Leuven, Belgium

2 Department of pathology, Radboud University Medical Center, Nijmegen, The Netherlands

3 Amgen Limited, Uxbridge Business Park, Sanderson Road, Uxbridge, UK

4 Amgen Inc: Morley Kimberlin, Thousand Oaks, CA, USA

5 Amgen NV/SA Belgium, Machelen, Belgium

*Corresponding author: Dequeker EMC

\section{$\risingdotseq$ els.dequeker@kuleuven.be}

Department of Public Health and Primary Care, Biomedical Quality Assurance Research Unit, University of Leuven, Leuven, Belgium

Tel: +3216379141

Citation: Dufraing K, Keppens C, Siebers AG, Kafatos G, Lowe K, et al. (2019) PreAnalytical Challenges during RAS Testing: Tissue Quality and the Estimation of Neoplastic Cell Percentage. Biomark J Vol.5 No.2:2

optimal cell block, delineation of the area for macro-dissection and the estimation of the neoplastic cell content are crucial to ensure achievement of the minimum percentage of neoplastic cells. Despite that testing strategies are becoming more sensitive, the need for accurate estimation is as important as ever. The use of Next-Generation-Sequencing (NGS) proves that knowing the tumor cellularity is essential to make a distinction between 
signals and noise [7]. In addition, samples containing a low number of neoplastic cells require higher coverages $[8,9]$.

Despite its importance in biomarker testing, there is currently no established method to optimally estimate the percentage of neoplastic cells [10]. Pathologists often receive a general training to estimate the percentage of neoplastic cells on hematoxylin and eosin (H\&E) stained Formalin-Fixed Paraffin-Embedded (FFPE) tissue slides. Various ways for doing this exist and previous studies have indicated that estimates between different pathologists can vary [11-13]. A recent large European-wide study confirmed these findings [14].

An interactive workshop was organized to resolve issues related to tissue quality as part of a larger study on neoplastic cell content. The aim of this workshop was to provide laboratories customized feedback on their laboratory performance during the European Society of Pathology (ESP) Colon EQA scheme of 2016.

\section{Methods}

Laboratories participating in the 2016 ESP Colon EQA scheme $(\mathrm{N}=105)$ on a voluntary basis, were invited to an interactive workshop organized by the Radboud University Medical Center in The Netherlands. Initially, a survey was carried out focused on pre- and post-analytical stages related to the determination of the neoplastic cell content. During a microscopic session, neoplastic cell percentages were estimated for five $H \& E$ stained tumor tissue slides from $\mathrm{mCRC}$ specimen. Estimates were provided before and after an expert in molecular pathology illustrated good practices for selecting the area for DNA extraction (e.g. how to avoid necrotic areas and lymphocytes) and the determination of the neoplastic cell content. This explanatory discussion gave pathologists the opportunity to elaborate on the sample characteristics required to be considered when determining the neoplastic cell content. Participants were also asked to score the difficulty of the cases based on the presence of other cell types such as the infiltration of immune cells, mucus, necrosis and desmoplastic stroma (Score 0 =very straightforward - score 3=very hard to determine).

\section{Results}

Nine participants from seven laboratories attended the workshop. The laboratory characteristics are shown in Table 1. Participants included four pathologists, three molecular biologists, a technologist and a clinical geneticist.

Based on the survey results, a description was created on the different pre- and post-analytical steps that are required to be taken by the participating laboratories for determining the neoplastic cell content (Figure 1). For six laboratories the neoplastic cell content was determined routinely by the pathologist using visual estimation. For the remaining laboratory, whole slide sections were routinely used. The participating laboratories responded that they never use any of the other methods for determining neoplastic cells i.e. manually counting individual cells or measurement by a computer system. They also stated that the neoplastic cell content is always determined by the pathologist as opposed to molecular biologist, technician or clinical scientist in molecular pathology. For all laboratories, macro-dissection followed the neoplastic cell content estimation. In 6 out of 7 of the laboratories that participated to the workshop the neoplastic cell percentage was included in the test report. However, only 4 laboratories took this into account for interpretation.

The average range of neoplastic cell content estimates during the microscopic session with the four pathologists before

Table 1: Characteristics of the laboratories that participated in the workshop.

\begin{tabular}{|c|c|c|c|c|c|c|c|}
\hline Lab id & Country & $\begin{array}{l}\text { Hospital } \\
\text { type }\end{array}$ & $\begin{array}{l}\text { Participant's } \\
\text { profession }\end{array}$ & $\begin{array}{l}\text { Number } \\
\text { of KRAS } \\
\text { samples } \\
\text { tested in } \\
\text { routine per } \\
\text { year }\end{array}$ & $\begin{array}{c}\text { Number } \\
\text { of NRAS } \\
\text { samples } \\
\text { tested in } \\
\text { routine per } \\
\text { year }\end{array}$ & Extraction method & Test method \\
\hline 1 & Turkey & Private & Clinical geneticist & $10-49$ & $10-49$ & $\begin{array}{c}\text { QIAamp DNA FFPE Tissue } \\
\text { Kit (Qiagen) }\end{array}$ & NGS: MiSeq (Illumina) \\
\hline 2 & Germany & $\begin{array}{l}\text { University } \\
\text { hospital }\end{array}$ & Pathologist & $250-499$ & $100-249$ & InnuPrep C16 FFPE Kit & $\begin{array}{c}\text { Commercial kit: Therascreen KRAS } \\
\text { Pyro Kit (Qiagen DxS) }\end{array}$ \\
\hline 3 & Austria & $\begin{array}{l}\text { General } \\
\text { hospital }\end{array}$ & $\begin{array}{c}\text { Pathologist \& } \\
\text { molecular biologist }\end{array}$ & $50-99$ & $10-49$ & $\begin{array}{c}\text { GeneRead DNA FFPE Kit } \\
\text { (Qiagen) }\end{array}$ & $\begin{array}{c}\text { Commercial kit: Cobas }{ }^{\circledR} \text { KRAS } \\
\text { Mutation Test (Roche) }\end{array}$ \\
\hline 4 & Romania & Private & Molecular biologist & $50-99$ & $10-49$ & $\begin{array}{c}\text { QIAamp DNA FFPE Tissue } \\
\text { Kit (Qiagen) }\end{array}$ & $\begin{array}{c}\text { Commercial kit: KRAS StripAssay }{ }^{\circledast} \\
\text { (Vienna-lab) }\end{array}$ \\
\hline 5 & Israel & $\begin{array}{l}\text { General } \\
\text { hospital }\end{array}$ & Molecular biologist & $250-499$ & $250-499$ & $\begin{array}{l}\text { QIAamp DNA Mini Kit } \\
\text { (Qiagen) }\end{array}$ & LDT: Allele-specific PCR assays \\
\hline 6 & Portugal & Private & $\begin{array}{c}\text { Pathologist \& } \\
\text { Laboratory technician }\end{array}$ & $100-249$ & $100-249$ & $\begin{array}{c}\text { QIAamp DNA Blood } \\
\text { Mini Kit (Qiagen), } \\
\text { additional digestion with } \\
\text { Proteinase K and buffer } \\
\text { ATL (Qiagen) }\end{array}$ & LDT: Dideoxy sequencing \\
\hline 7 & $\begin{array}{c}\text { The } \\
\text { Netherlands }\end{array}$ & $\begin{array}{l}\text { University } \\
\text { hospital }\end{array}$ & Pathologist & $250-499$ & $250-499$ & $\begin{array}{l}\text { QIAamp DNA Mini Kit } \\
\text { (Qiagen) }\end{array}$ & $\begin{array}{l}\text { NGS: smMIPS and in-house primers } \\
\text { based on Ion AmpliSeq Colon and } \\
\text { Lung Cancer Panel (Life Technologies) }\end{array}$ \\
\hline \multicolumn{8}{|c|}{ NGS } \\
\hline
\end{tabular}




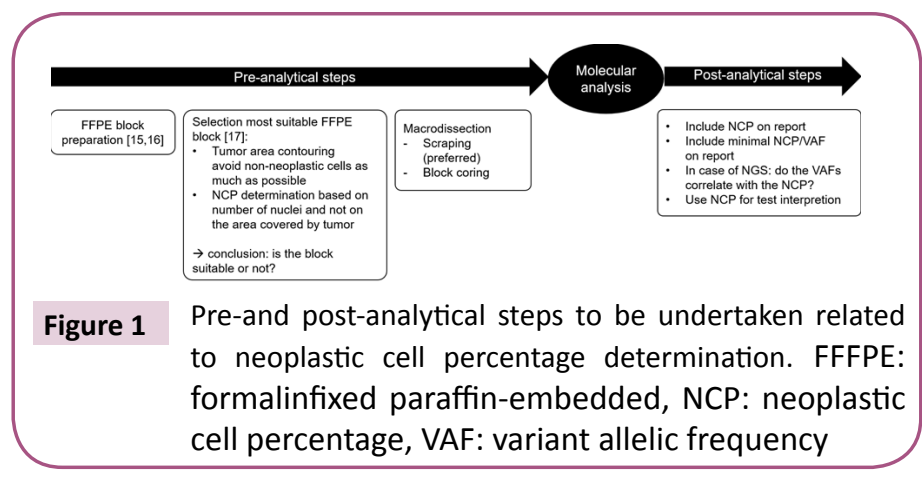

the explanatory discussion was $22 \%$ (Figure 2). During an explanatory session the pathologists discussed the difficulty level of each sample and which factors they take into account when estimating the neoplastic cell content (Table 2). For samples where the immune cells have been infiltrated and necrosis is present, some pathologists suggested they may be overcautious and underestimate the percentage of neoplastic cells. This was the case for sample 4, where both the estimates and the variation increased following the discussion. The average range of neoplastic cell content estimates were 19\% following the feedback provided (Figure 2). In all other cases the variation between pathologists remained the same or decreased.

\section{Discussion}

The existing EQA programs in Europe ensure high quality of biomarker testing. The workshop carried out at the Radboud University provided feedback to laboratories aiming to further improve the pathology center technical methods. Accurate estimation of the neoplastic cell content is important to ensure no samples are misclassified as wild type. During the workshop differences were observed for the indication of micro- or macrodissection and the estimation of the neoplastic cell content between the participants. Despite the low participant numbers, this study was able to identify the critical differences. These findings are in line with a recent study in which variation between neoplastic cell content estimates and tumor area delineations between different pathologists were calculated based on EQA results [14].

Both in the pre-and post-analytical phase of the testing process attention should be paid to the suitability of the starting material. When preparing the FFPE block, appropriate fixatives and fixation times should be used, as described elsewhere $[15,16]$. Hematoxylin and eosin stained slides from the FFPE blocks should be checked for their suitability based on the absolute and relative number of neoplastic cells. To avoid non-neoplastic cells to dilute the sample, a limited area can be contoured for macrodissection. The latter can be done by scraping the tissue from the slide or by coring the block. After molecular analysis it is important to include the estimated NCP on the testing report and to correlate it with 1 ) the minimum NCP required by the testing method and 2) the allelic frequency of the variants identified. If the NCP is lower or near the minimal requirement, this should be considered when interpreting the testing result.

Setting a standard for neoplastic cell percentage determination is thus required to improve biomarker testing. ISO 15189, an
Table 2: Characteristics of the five H\&E stained tumor tissue slides.

\begin{tabular}{|c|c|c|c|c|c|}
\hline & Case 1 & Case 2 & Case 3 & Case 4 & Case 5 \\
\hline Average difficulty level* & 0.5 & 0.5 & 2 & 1.5 & 1 \\
\hline \multicolumn{6}{|l|}{ Difficulty factors: } \\
\hline Infiltration of immune cells & $\checkmark$ & & $\checkmark$ & $\checkmark$ & $\checkmark$ \\
\hline Desmoplastic stroma & $\checkmark$ & $\checkmark$ & & & \\
\hline Mucus & & & & $\checkmark$ & \\
\hline Necrosis & & $\checkmark$ & $\checkmark$ & & \\
\hline \multicolumn{6}{|c|}{$\begin{array}{l}\text { *Participants scored the level of difference of the sample. A score } \\
\text { between } 0 \text { (very straight forward) and } 3 \text { (hard to determine) could be } \\
\text { given. }\end{array}$} \\
\hline
\end{tabular}

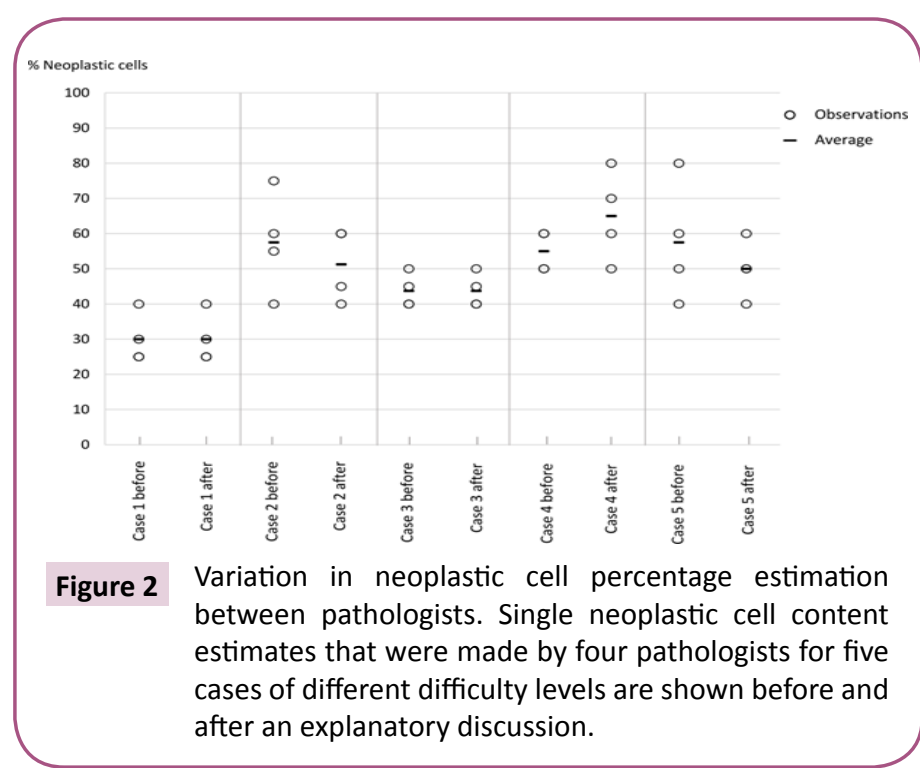

international standard for medical laboratory testing, clearly states that laboratories have to select procedures which have been validated for their intended use and have to document these procedures [17]. Yet, most laboratories see this step as 'trivial' and have no written procedures. A study has already been set-up by the KU Leuven and Radboud University in which experts from ten European countries aim to obtain consensus regarding a best-practice guideline for the determining of the neoplastic cell content.

Laboratories should acknowledge the importance of interobserver tuning within their laboratory on a regular basis, which is also a requirement for ISO 15189 [18]. A discussion between pathologists regarding factors impacting the neoplastic cell content percentage (e.g. infiltration of immune cells and necrosis) could also be useful. Finally, pathologists need to continuously evaluate their techniques by regularly re-estimating samples' neoplastic cell content.

Apart from the determination of neoplastic cell content, other pre-analytical stages should be validated and documented, taking into account other factors that may impact the test outcome. Further research into the pre-analytical phase would be beneficial to investigate this in systematic way. The post-analytical phase could also be improved by adding a warning note when the 
neoplastic cell content reaches the minimal percentage needed for the test method.

\section{Conclusion}

As a conclusion, this paper describes a pathology workshop that was carried out aiming to further improve biomarker testing in Europe. During the workshop the importance of the preanalytical phase was stressed and feedback was provided to the participating pathologists. Such initiatives are important as they contribute to paving the way towards standardized practices and improving biomarker testing standards in Europe.

\section{Compliance with Ethical Standards}

\section{Conflicts of interest}

Dufraing K, Keppens C, Siebers AG and Dequeker EMC. nothing to declare Kafatos G, Lowe K, Demonty $G$ are employees and shareholders of Amgen. Van Krieken $\mathrm{JH}$ had research grant funding from Amgen

\section{Funding}

The study was funded by Amgen (Europe) $\mathrm{GmbH}$.

\section{Contribution}

Dufraing K, Kafatos G, Dequeker EMC and van Krieken JH conceived and designed the study. Dufraing K, Keppens $C$, Dequeker EMC and van Krieken JH researched and analyzed data. Dufraing K, Keppens C, Siebers AG, Kafatos G, Lowe K, Demonty $G$, Dequeker EMC and van Krieken JH wrote, edited and reviewed the manuscript. All authors gave final approval for publication. Dequeker EMC takes full responsibility for the work as a whole, including the study design, access to data and the decision to submit and publish the manuscript.

\section{Acknowledgement}

The authors want to thank the participating laboratories for their input to the workshop.

\section{References}

1. Battaglin F, Dadduzio V, Bergamo F, Manai C, Schirripa M, et al. (2017) Anti-EGFR monoclonal antibody panitumumab for the treatment of patients with metastatic colorectal cancer: an overview of current practice and future perspectives. Expert Opin Biol Ther 17: 1297-1308.

2. Chen H, Luthra R, Goswami RS, Singh RR, Roy-Chowdhuri $S$ (2015) Analysis of Pre-Analytic Factors Affecting the Success of Clinical Next-Generation Sequencing of Solid Organ Malignancies. Cancers (Basel) 7: 1699-1715.

3. Keppens C, Dufraing K, Van Krieken H, Siebers AG, Kafatos G, et al. (2017) Laboratory errors in the diagnostic process of RAS testing in Europe. Abstract submitted for ECP, Amsterdam, The Netherlands.

4. Rao S, Masilamani S, Sundaram S, Duvuru P, Swaminathan R
(2016) Quality Measures in Pre-Analytical Phase of Tissue Processing: Understanding Its Value in Histopathology. J Clin Diagn Res 10: EC07-EC11.

5. Tack V, Ligtenberg MJL, Siebers AG, Rombout PDM, Dabir PD, et al. (2017) RAS testing for colorectal cancer patients is reliable in European laboratories that pass external quality assessment. Virchows Arch 472: 717-725.

6. Loree JM, Kopetz S, Raghav KP (2017) Current companion diagnostics in advanced colorectal cancer; getting a bigger and better piece of the pie. J Gastrointest Oncol 8: 199-212.

7. Strom SP (2016) Current practices and guidelines for clinical next-generation sequencing oncology testing. Cancer Biol Med 13: 3-11.

8. Jennings LJ, Arcila ME, Corless C, Kamel-Reid S, Lubin IM, et al. (2017) Guidelines for Validation of Next-Generation Sequencing-Based Oncology Panels: A Joint Consensus Recommendation of the Association for Molecular Pathology and College of American Pathologists. J Mol Diagn 19: 341365.

9. Lin MT, Mosier SL, Thiess M, Beierl KF, Debeljak $M$, et al. (2014) Clinical validation of KRAS, BRAF, and EGFR mutation detection using next-generation sequencing. Am J Clin Pathol 141: 856-866.

10. Van Krieken JH, Normanno N, Blackhall F, Boone E, Botti G, et al. (2013) Guideline on the requirements of external quality assessment programs in molecular pathology. Virchows Arch 462: 27-37.

11. Lhermitte B, Egele C, Weingertner N, Ambrosetti D, Dadone $B$, et al. (2017) Adequately defining tumor cell proportion in tissue samples for molecular testing improves interobserver reproducibility of its assessment. Virchows Arch 470: 21-27.

12. Smits AJ, Kummer JA, de Bruin PC, Bol M, van den Tweel JG, et al. (2014) The estimation of tumor cell percentage for molecular testing by pathologists is not accurate. Mod Pathol 27: 168-174.

13. Viray H, Li K, Long TA, Vasalos P, Bridge JA, et al. (2013) A prospective, multi-institutional diagnostic trial to determine pathologist accuracy in estimation of percentage of malignant cells. Arch Pathol Lab Med 137: 1545-1549.

14. Dufraing K, De Hertogh G, Tack V, Keppens C, Dequeker E, et al. (2017) External quality assessment identifies training needs to determine the neoplastic cell content for biomarker testing. J Mol Diagn 20: 455-464.

15. Araujo LH, Timmers C, Shilo K, Zhao W, Zhang J, et al. (2015) Impact of Pre-Analytical Variables on Cancer Targeted Gene Sequencing Efficiency. PLoS ONE 10: e0143092.

16. Amemiyaa K, Hirotsua Y, Oyamab T, Omata M (2019) Relationship between formalin reagent and success rate of targeted sequencing analysis using formalin fixed paraffin embedded tissues. Clinica Chimica Acta 488: 129-134. 
17. Dufraing K, van Krieken JH, De Hertogh G, Hoefler G, Oniscu A (2019) Neoplastic cell percentage estimation in tissue samples for molecular oncology: recommendations from a modified Delphi study. Histopathology.
18. International Organization for Standardization, ISO 15189:2012 Medical laboratories - Particular requirements for quality and competence. ISO, Geneva, 2012. 